\title{
ÁTLAGOS FELÜLETI ÉRDESSÉG VIZSGÁLATA VÍZVÁGÁS TECHNOLÓGIÁJÁNÁL
}

\section{EXAMINATION OF AVERAGE SURFACE ROUGHNESS $(R a)$ IN WATER JET CUTTING TECHNOLOGY}

\author{
Horváth Richárd ${ }^{1}$, Drégelyi-Kiss Ágota ${ }^{2}$ \\ Óbudai Egyetem, Bánki Donát Gépész és Biztonságtechnikai Mérnöki Kar, Anyag- \\ tudományi és Gyártástechnológiai Intézet Cím: 1081, Magyarország, Budapest, \\ Népszínház utca, 8.; Telefon: +36-1-666-5326, \\ horvath.richard@bgk.uni-obuda.hu \\ 2dregelyi.agota@bgk.uni-obuda.hu
}

\begin{abstract}
One of the non-conventional cutting technologies is the WaterJet cutting. There are two important criteria of the cut surface: the geometric accuracy and the surface roughness. The aim of this paper is to provide predictive models to estimate average surface roughness $(R a)$, taking into account significant effects. It was used a full factorial design of experiments in the waterjet cutting tests. The three input parameters were plate thickness $(\mathrm{mm})$, grain mass $(\mathrm{g} / \mathrm{min})$, and feed rate $(\mathrm{mm} / \mathrm{min})$. The thickness of the cut plate has a great influence in the quality of the waterjet cut surface (due to the bending of the waterjet or the pressure decrease, etc.), therefore surface roughness was measured in three places along the thickness of the plate and so three predictive models were constructed.
\end{abstract}

Keywords: waterjet, average surface roughness (Ra), phenomenological model, design of experiment

\section{Összefoglalás}

A vízvágás, a nem hagyományos elven alapuló technológiák közé tartozik. A vágott felület fontos kritériumai közé sorolható a felület geometriai pontossága, valamint a vízvágás által kialakított felületi érdesség. A tanulmány célja, hogy a szignifikáns hatásokat figyelembe véve prediktív modelleket alkossunk az átlagos érdességi $(R a)$ értékek becslésére. A vízvágási tesztekhez $3^{3}$-os teljes faktoros kísérlettervet alkalmaztunk, melyben bemenő paraméterekként a lemezvastagság, mm, a szemcsemenynyiség, g/min illetve az elötoló sebesség, $\mathrm{mm} / \mathrm{min}$ voltak. A forgácsolt felület minősége nagyban változik a vágott lemez vastagságával (pl.: a vízsugár elhajlás és nyomáscsökkenés miatt), ezért a felületi érdességet három helyen mértük a vágott lemezek vastagságán, és három prediktív modellt állítottunk fel.

Kulcsszavak: vízvágás, átlagos felületi érdesség (Ra), fenomenológiai modell, teljes faktoriális kisérlettervezés

\section{Bevezetés}

Az elmúlt évtizedekben a nem hagyományos elvek szerint müködő forgácsoló eljárások rohamos mértékben terjednek. A vízsugárral való vágás olyan hideg vágási eljárás ahol a víz és általában az ehhez kevert abrazív adalékanyag kapcsolata olyan 
sokélű forgácsolószerszám alapját képezi, ami optimális felhasználás mellett alkalmas lehet lemezszerü alkatrészek kuntúrjának kivágására.

A vízsugárral való megmunkáláshoz nagy anyagleválasztási sebesség kell, melynek energiáját a kis átmérőjű fúvókanyíláson átáramló nagy nyomású víz teszi lehetővé. A vízvágás további nagy előnye, hogy nem használ fel, illetve megmunkálás közben nem keletkeznek a környezetre káros anyagok. Pozitív tulajdonságai közül fontos még kiemelni, hogy a vágás következtében (föként fémek esetében) nem változik meg a vágott felület tulajdonsága, hiszen megmunkáláskor azt nem éri hőhatás.

Jegaraj és Babu [1] abrazív szemcsékkel történő vízvágás technológiáját vizsgálták. Kutatásukban elemezték a fókusztávolság és a fúvókanyílás nagyságának hatását a vízvágás technológiára 6063-T6 alumínium ötvözet esetében. Munkájukban Taguchi módszert alkalmaztak, valamint empirikus modelt építettek. Eredményeikből azt a következtetést vonták le, hogy a vízvágott felületi érdességre nagy hatása van a vízsugár átmérőjének (fúvókanyílás), az vízsugár előtolási sebességének, valamint a vízsugár nyomásának.

Valíček és társai [2] a vízvágással készített felület topográfiáját vizsgálták és optimalizálták a beállítható paraméterek függvényében vízvágás technológiájánál.

Srinivasu és Babu [3] prediktív modelt alkottak neurális háló (ANN) módszerével, melyben bemenő paraméterként felhasználták a szabályozható paramétereket úgymint: a fúvóka átmérője, a víz nyomása, valamint az előtolási sebesség.

Alumínium ötvözetek vízsugaras vágásának tapasztalatait összegezte Maros [4] [5].

Ebben a cikkben vízvágott felületek érdességével foglalkozunk acél munkadarab esetében. A vízvágási tesztekhez teljes faktoriális kísérlettervet használtunk, ahol három szabályozható paramétert három szin- ten változtattunk (lemezvastagság, előtolási sebesség, vízsugárhoz adagolt szemcsemennyiség). Célunk olyan prediktív modell létrehozása, mellyel könnyen becsülhető a vízvágott felületek átlagos felületi érdessége $(\mathrm{Ra})$ a vágási mélység teljes hosszában.

\section{Anyagok és módszerek}

\subsection{Felhasznált eszközök}

A kísérletre használt gép, egy Byjet 4022 típusú vízvágógép, melynek munkaterülete $4020 \times 2010 \mathrm{~mm}$, a szivattyú által elöállított nyomás 4000 bar.

A kísérleteknél használt abrazív szemcse úgynevezett Supreme Garnet, indiai gránáthomok. Szemcsemérete: $0,125-0,40$ mm, keménysége: 7,0-7,5 Mohs.

A vívágási kísérlethez felhasznált munkadarabok anyaga S355-ös acél.

$\mathrm{Az}$ átlagos felületi érdesség (Ra) méréséhez Surftest SJ301 (Mitutoyo) típusú mérőgépet használtunk.

\subsection{Alkalmazott kísérletterv}

A tesztekhez $3^{3}$-os teljes faktoros kísérlettervet használtunk, ahol a három bemenő független változó a lemezvastagság $(\mathrm{mm}) \mathrm{a}$ szemcsemennyiség $(\mathrm{g} / \mathrm{min})$ illetve az előtoló sebesség $(\mathrm{mm} / \mathrm{min})$ voltak.

Célunk, hogy a kísérletterv mérési pontjaiból az alábbi alakban jól használható prediktív modellt építsünk a gyártott felületi érdesség áltagos értékeinek becslésére:

$$
Y=e^{c_{0}+c_{1} \cdot X_{1}+c_{2} \cdot X_{2}+c_{3} \cdot X_{3}}
$$

ahol, $Y$ - a válaszfüggvény;

$X_{1}, X_{2}, X_{3}$ - a bemenő paraméterek;

$c_{0}, c_{1}, c_{2}, c_{3}$-empirikus konstansok.

\subsection{Kísérleti pontok meghatározása}

A $3^{3}$-os teljes faktoros kísérlettervböl adódik a 27 mérési pont. A három független bemenő változó és ezek beállítató értékeik a következők:

- Lemezvastagság $(t)$ : 15-25-35 mm;

- Szemcsemennyiség $(g)$ : 300-350-400 g/min, 
-Előtoló sebesség $\left(v_{f}\right)$ : minimális érték középérték, maximális érték, $\mathrm{mm} / \mathrm{min}(\mathrm{Az}$ elötoló sebesség értékei függnek a lemezvastagságtól. $\mathrm{L}=15 \mathrm{~mm}$ vastagságú anyag esetében: $50-75-100 \mathrm{~mm} / \mathrm{min}$; $\mathrm{L}=25 \mathrm{~mm}$ vastagságú anyag esetén: 2233-44 $\mathrm{mm} / \mathrm{min}$, valamint $\mathrm{L}=35 \mathrm{~mm}$ vastagságú anyag esetén: 13-19-25 $\mathrm{mm} / \mathrm{min}$.)

\section{Eredmények}

Mivel a felületi érdesség nagyban változik a vágási méység függvényében, ezért az átlagos felületi érdességet (Ra) három helyen mértük (a vízsugár belépési helyén, középen és a vízsugár kilépési helyén). A munkadarabon a felületi érdesség mérési helyeit és a mérés elrendezését mutatja az 1. ábra. Minden érdességi mérést kétszer ismételtünk meg.
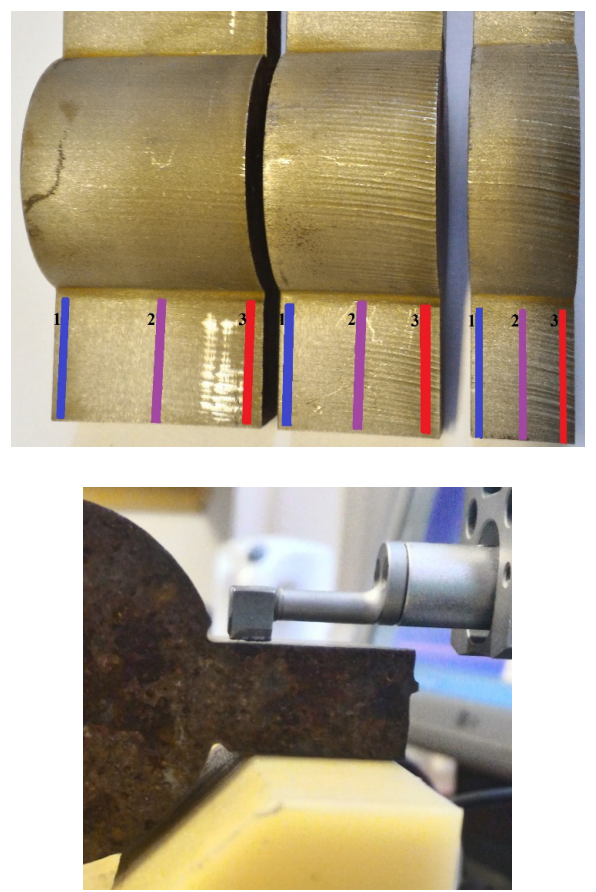

1. ábra. Felületi érdesség mérésének helyei és a mérés elrendezése

\subsection{Empirikus model az átlagos felü- leti érdesség $(R a)$ becslésére}

$\mathrm{Az}$ átlagos felületi érdesség becslésére az (1) egyenlet szerint a prediktív modell a következő:

$$
R a=e^{c_{0}+0,019 \cdot t-0,0028 \cdot g+0,012 \cdot v_{f}}
$$

ahol, $t$ - lemez vastagság, mm; $g$ - szemcse mennyiség, $\mathrm{g} / \mathrm{min}$; $v_{f}$ - elötoló sebesség, $\mathrm{mm} / \mathrm{min}$; $c_{0}-$ mérési helytől függő konstans.

A $c_{0}$ értékei a következőek (1. ábra alapján):

1. mérési helyen: 1,491 ;

2. mérési helyen: 1,813 ;

3. mérési helyen: 2,421 .

$\mathrm{Az}$ előtolás és a szemcsemennyiség hatását a vízvágott felületi érdességre jól mutatja a (2) egyenlet grafikus ábrázolása (2. ábra).

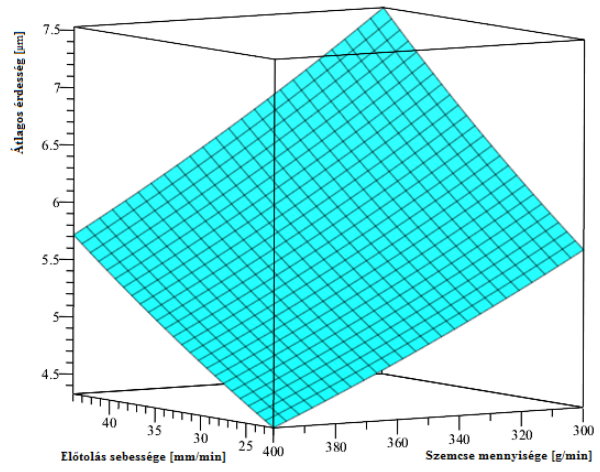

2. ábra. Átlagos érdesség értékei az elötolás sebessége és a szemcse mennyiség függvényében (középsö-2-mérési hely; $t=25 \mathrm{~mm}$ )

\subsection{Reziduumok vizsgálata}

A 3. ábra az átlagos érdességi paraméter (Ra) mért és számolt értékeinek különbégét mutatja hisztogrammon. Az ábrából jól látható, hogy a modell pontossága romlik (a mért és becsült értékek közötti különbség - hiba - szórása növekszik) a vágási mélység függvényében. De mindhárom mérési 
helyen viszonylag kis szórással és a technológiai tervezésben megfelelő pontosággal használható az épített (2) empirikus modell.

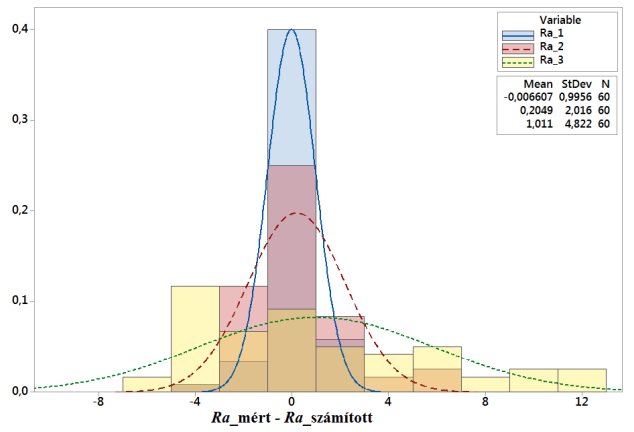

3. ábra. $A$ (2) egyenlet hibái hisztogramon ábrázolva (mindhárom mérési helynél)

\section{Következtetések}

Ebben a cikkben vízvágás technológiájával elérhető felületi érdességet vizsgáltuk. A kísérletekhez teljes faktoriális kísérlettervet alkalmaztunk, majd empirikus modellt építettünk az átlagos felületi érdesség becslésére a bemenő paraméterek (lemezvastagság, szemcsemennyiség, előtoló sebesség) függvényében. A vizsgálatainkból a következőek vonhatoak le:

- Az általunk épített egyenlet megfelelő pontosággal becsli az átlagos felületi érdesség várható értékét.

- A modell pontossága kissé romlik a vágott felület mélyégének függvényében.

- A modell hibái normál eloszlást követnek.

\section{Köszönetnyilvánítás}

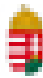

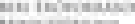

Az EMBERI ERŐFORRÁSOK

MINISZTÉRIUMA ÚNKP-16-4/I. KÓDSZÁMÚ ÚJ

NEMZETI KIVÁLÓSÁG PROGRAMJÁNAK

TÁMOGATÁSÁVAL KÉSZÜLT

\section{Szakirodalmi hivatkozások}

[1] J. Jegaraj, J. R., Babu, N. R.: A soft computing approach for controlling the quality of cut with abrasive waterjet cutting system experiencing orifice and focusing tube wear. Journal of Materials Processing Technology 185, 2007, 217-227.

[2] Valíček, J., Harničárová, M., Kušnerová, M., Grznárik, R., Zavadil, J.: Proposition of a Solution for the Setting of the Abrasive Waterjet Cutting Technology. Measurement science review, Volume 13, No. 5, 2013, 279-285.

[3] Srinivasu, D.S., Babu N. R.: A neuro-genetic approach for selection of process parameters in abrasive waterjet cutting considering variation in diameter of focusing nozzle. Applied Soft Computing 8, 2008, 809-819.

[4] Maros, Zs.: Taper of cut at abrasive waterjet cutting of an aluminium alloy. Journal of Production Processes and Systems, vol. 6. No. 1., 2012, 55-60.

[5] Maros, Zs.: Energy approach of the taper at abrasive waterjet cutting. Production Processes and Systems, vol. 6. No. 1., 2013, 89-96. 